\title{
XILOTECNIA OF THE WOOD OF Acacia Schaffneri FROM THE STATE OF HIDALGO, MEXICO
}

\author{
Roberto Machuca-Velasco ${ }^{1}$, Amparo Borja de la Rosa ${ }^{1, \diamond}$, Alejandro Corona-Ambriz, \\ Idalia Zaragoza-Hernández ${ }^{1}$, Jesús Guadalupe Arreola-Avila ${ }^{1}$, Javier Jiménez-Machorro ${ }^{1}$
}

\begin{abstract}
The genus Acacia spp belongs to the family Leguminosae, with more than 1300 species distributed naturally in all continents except Europe. In Mexico there are 85 species, of which 46 are endemic, most located in arid and semiarid regions, being Acacia coulteri and Acacia farnesiana the most widely distributed. The aim of this study was to determine the technological characteristics of the wood of Acacia schaffneri. To determine the anatomical characteristics, the methodology of Autonomous Chapingo University's wood anatomy laboratory was used; for the physical properties, standards NOM EE-117-1981 and NMX-EE-167-1983 were used, and in calculating the mechanical properties the mathematical formulas were employed. The wood is reddish brown and has interlocked grain with diffuse porosity, aliform confluent parenchyma and in confluent bands, and crystals and gums. The proportion of cells was $11,87 \%$ vessel elements, $50,65 \%$ fibers $27,76 \%$ axial parenchyma and $9,81 \%$ ray parenchyma. Basic density was $880 \mathrm{~kg} / \mathrm{m}^{3}$, tangential, radial, axial and volumetric shrinkage values were $10,57 \% ; 4,97 \% ; 0,10 \%$ and $15,82 \%$ respectively, and fiber saturation point was $19,97 \%$. The mechanical properties were very high, so it can be used in the manufacture of floors and in building constructions.
\end{abstract}

Keywords: Fiber saturation point, mechanical properties, physical properties, pulp quality indices, wood anatomy.

\section{INTRODUCTION}

The genus Acacia spp belongs to the family Leguminosae, subfamily Mimosoideae with more than 1300 species, which are distributed naturally in all continents except Europe. More than 900 species are native to Australia and the rest to dry tropical and warm temperate regions of Africa, southern Asia and the Americas.

With regard to the species found in the Americas, there is little information. Probably the best known are: Acacia coulteri in northern Mexico; Acacia caven in Argentina, Bolivia, Brazil, Chile, Paraguay and Uruguay; Acacia aroma in Argentina, Bolivia, Ecuador, Paraguay and Peru; Acacia adstringens in areas of Argentina, Paraguay and Peru; and Acacia farnesiana in Mexico and Central America (Barros 2007). 
In Mexico there are 85 species, of which 46 are endemic, most located in arid and semi-arid regions, which shows the ecological tolerance of the genus; for example, Acacia farnesiana is present throughout the country, covering a wide variety of climates and ecosystems (altitudes of 0-2600 m, temperatures of $5-30{ }^{\circ} \mathrm{C}$ and rainfall of $100-900 \mathrm{~mm}$ annually on average). A. schaffneri is located mainly in the northern and eastern region of the country, and it is commonly associated with $A$. farnesiana.

The genera Prosopis and Acacia are part of the thorn forest, constitute the main woody cover in the dry tropics and subtropics, tolerate extreme drought and have the ability to fix atmospheric nitrogen, so they play an important role in soil conservation, making them key genera in Mexico's arid and semiarid ecosystems (Gómez and Tapia 2003). Specifically, the fruit of Acacia schaffneri has active anti-cancer and anti-inflammatory ingredients (Manríquez 2013).

Concerning the wood, studies of different species have been conducted. These include: the Australian blackwood (Acacia melanoxylon), which has a basic density of $430 \mathrm{~kg} / \mathrm{m}^{3}$, and tangential and radial shrinkage at $12 \% \mathrm{MC}$ of $4,2 \%$ and 3,6\% respectively; silver wattle (Acacia dealbata), with a basic density of $470 \mathrm{~kg} / \mathrm{m}^{3}$ and tangential and radial shrinkage at $12 \% \mathrm{MC}$ of $5,0 \%$ and $4,4 \%$ respectively (Ananías et al. 2008). In Argentina, Acacia melanoxylon had radial shrinkage of 3,82\% and $7,38 \%$ in the tangential direction. The fiber saturation point value was $24,7 \%$ and the average normal density was $604 \mathrm{~kg} / \mathrm{m}^{3}$ (moisture content range of 10-18\%) (Igartúa et al. 2009).

On the other hand, Correa (2011) mentions that Acacia melanoxylum wood has gained wide acceptance in the market because it is easy to saw, having a basic density of 540 to $750 \mathrm{~kg} / \mathrm{m}^{3}$, suitably supports tensile and compression stresses, is resistant to shock and vibration, and has a fine finish. It is used in the manufacture of furniture, interior linings, joinery, turnery, parquet flooring, musical instruments, and ship structures.

Huicochea-Santana and Barajas-Morales (2002) mention some characteristics of the wood of Acacia farnesiana, such as its yellowish creamy-colored sapwood with conspicuous and coalescent bands of paratracheal parenchyma, and its use in flooring (parquet). In Mexico its use is restricted to forage and logging for fence posts. The above-mentioned authors also report that Acacia cochliacantha has small, reddish brown heartwood with violet tones. It is tasteless, smells like guaje, and has no luster, and it is also characterized by medium texture, irregular grain, slightly pronounced figure, diffuse porosity, aliform parenchyma, multiseriate homogeneous rays, libriform fibers, a thick cell wall and specific gravity of $940 \mathrm{~kg} / \mathrm{m}^{3}$.

Finally, Acacia bilimecki has greyish heartwood with reddish tones, low luster, medium to fine texture, diffuse porosity, and very abundant confluent-aliform paratracheal axial parenchyma, with chains of prismatic crystals. The rays are moderately numerous, homogeneous and mainly triseriate. Fibers are $1168 \mathrm{~mm}$ in length and $12 \mathrm{~mm}$ in diameter, cell wall thickness is $4 \mathrm{~mm}$, and specific gravity ranges from 880 to $970 \mathrm{~kg} / \mathrm{m}^{3}$; it is used for wooden posts in rural housing construction.

Regarding the wood of Acacia schaffneri, it has a basic density ranging from 880 to $970 \mathrm{~kg} / \mathrm{m}^{3}$, a modulus of elasticity of $15,13 \mathrm{GPa}$, and a modulus of rupture of $207 \mathrm{MPa}$; it is used for fuel (firewood), fences, construction and tools. It is also regarded as a melliferous, medicinal species, and as food for goats and sheep (Foroughbakhch et al. 2012, Carrillo et al. 2011, Conafor 2008, González 2007, Rico 2001).

Therefore, it is necessary to know the anatomical characteristics and the physical and mechanical properties of Acacia schaffneri wood, obtained from a plantation, in order to properly use it and to suggest new uses. 


\section{MATERIALS AND METHODS}

\section{Study area location}

The municipality is located between $19^{\circ} 57^{\prime}$ north latitude and $98^{\circ} 55^{\prime}$ west longitude, at an altitude of 2360 meters. It is bordered to the north by San Agustín Tlaxiaca and Zapotlán, to the south by Tizayuca and the State of Mexico, to the east by Tezontepec and Zapotlán, and to the west by the State of Mexico (Figure1).
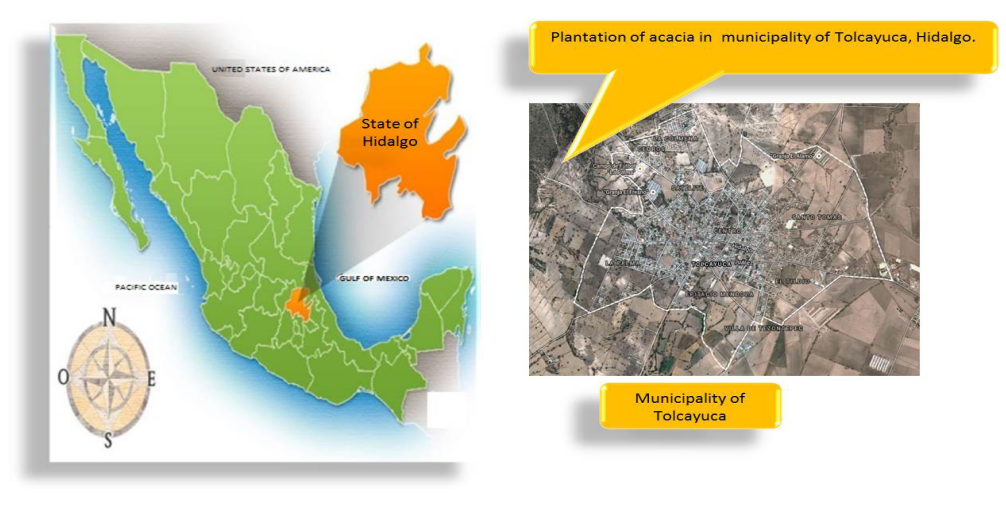

Figure 1. Study area location.

\section{Physical aspects}

The area's climate has an average annual temperature of $16,2^{\circ} \mathrm{C}$ and $557 \mathrm{~mm}$ rainfall. The soil type is semi-desert. The municipality is traversed by the Panuco and Moctezuma rivers. The vegetation consists of unarmed and thorny bushes such as Agave spp. (maguey), Pachycereus pringlei (S. Watson) Britton \& Roseel (cardón), Opuntia spp. (prickly pear), Schinus molle L. (Peruvian peppertree) and Yucca spp. (yucca).

The fauna consists of Canis latrans Say (coyote), Canis lupus L. (wolf), Mephitis macroura Lichtenstein (skunk), Oryctolagus cuniculus (rabbit), and Sciurus sp. (squirrel), along with reptiles, insects and a wide variety of arachnids, plus Carduelis carduelis L. (finches), Colibries spp (hummingbirds), Passer domesticus L. (sparrows) and Serinus canaria L (canaries).

\section{Description of the species}

Acacia schaffneri (S. Watson) F.J. Herm. belongs to the family Mimosaceae (J. Wash. Acad. Sci. 38: 236, 1948). It is commonly called twisted acacia or Schaffner's acacia in the United States, and huizache chino in Mexico. Synonyms include Pithecellobium schaffneri (S. Watson 1882), Samanea schaffneri (J.F. Macbr. 1919), and Vachellia schaffneri (S. Watson, Seigler \& Ebinger 2006).

The species is distributed in Texas, United States, and in the following states of Mexico: Aguascalientes, Baja California, Chihuahua, Coahuila, Durango, State of Mexico, Guanajuato, Jalisco, Michoacán, Nuevo León, Oaxaca, Puebla, Querétaro, San Luis Potosí, Sonora, Tamaulipas, Veracruz and Zacatecas, plus Mexico City.

Acacia schaffneri is part of the thornscrub. It is associated with Prosopis laevigata (mesquite), grows on stony slopes or flat terrain, from 1400-2500 masl, in shallow, chalky, sandy, stony, welldrained soils, with $\mathrm{pH} 5$ to 8 , and tolerates drought and frost. The trees have short, slender boles, branched from the base, with numerous stems. 
The trees have alternate, bipinnate-compound leaves, ranging from 2,5 to 5 centimeters long. The flower is a group of inflorescences arranged in spherical heads, from 6 to $9 \mathrm{~mm}$ in diameter, solitary or in groups of two to five; the fruit is a linear, slightly-flattened, but turgid pod, straight or slightly curved (legume), from 7 to $15 \mathrm{~cm}$ long and 5 to $8 \mathrm{~mm}$ wide.

\section{Material collection}

The material was collected in an area with a $15 \%$ slope. It is located at 2459 masl, at coordinates $19^{\circ} 56,964$ N; $98^{\circ} 57^{\prime} 12,74^{\prime \prime} \mathrm{W} ; 14$ 5047' 86" E and 220 56 '81" N ( PGS NAD 27 UTM).

The species is associated with huizcolote (Mimosa sp), prickly pear (Opuntia spp.), Mexican kidneywood (Eysenhardtia polystachya (Ort.) Sarg. 9), Peruvian peppertree (Schinus molle L.), pitaya (Stenocereus queretaroensis (F.A.C. WeBER) BuxB.) and Texas mimosa (Mimosa biuncifera Benth).

\section{Field procedures}

From one of the 9 trees collected, two botanical samples, from which total height and diameter at breast height (DBH) (Table 1) were determined, and a log section of approximately 1,20 m (Figure 2) were obtained.

Table 1. Dendrometric characteristics of the trees of Acacia schaffneri from Tolcayuca Hidalgo.

\begin{tabular}{|c|c|c|c|}
\hline No. of tree & Diameter $(\mathrm{cm})$ & Height $(\mathrm{m})$ & Slope (\%) \\
\hline 1 & 26,5 & 2,50 & 13 \\
\hline 2 & 29,00 & 3,0 & 15 \\
\hline 3 & 19,00 & 3,0 & 15 \\
\hline 4 & 34,0 & 3,5 & 0,0 \\
\hline 5 & 22,5 & 3,40 & 10 \\
\hline 6 & 23,0 & 2,80 & 10 \\
\hline 7 & 28,0 & 27,0 & 10 \\
\hline 8 & 22,0 & 3,50 & 10 \\
\hline 9 & 23 & 3,0 & 10 \\
\hline
\end{tabular}
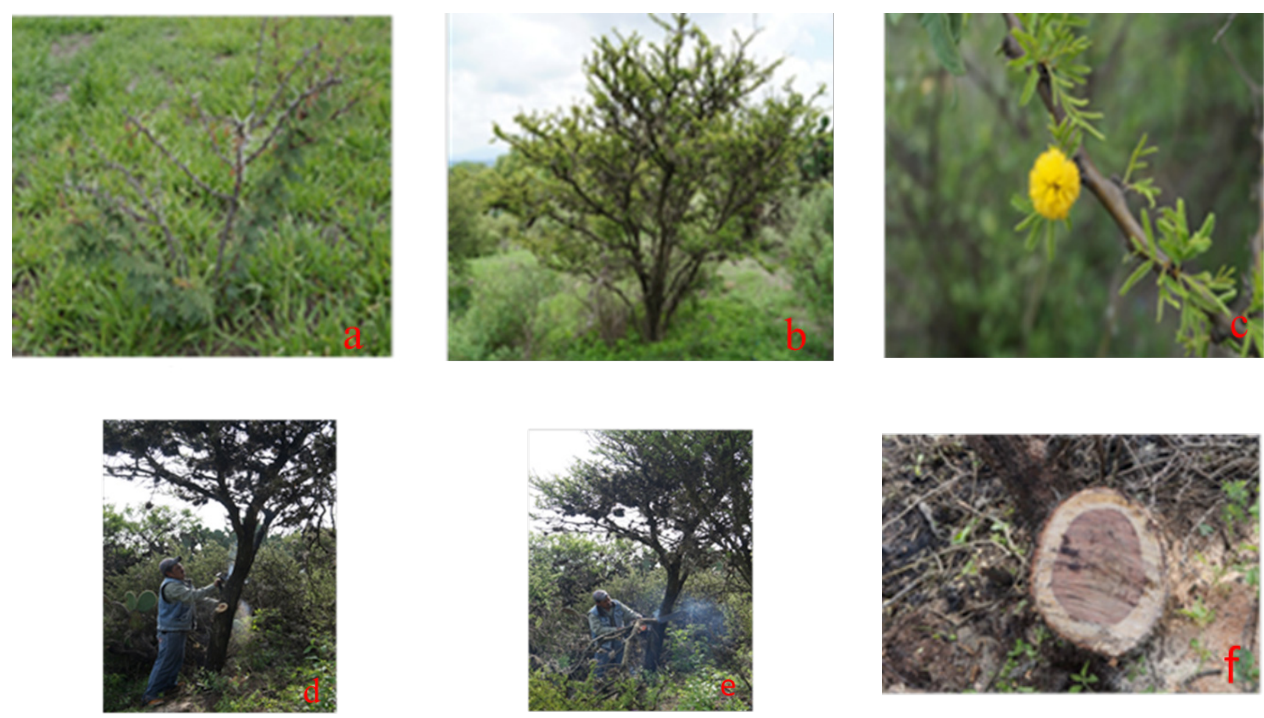

Figure 2. Acacia schaffneri from Tolcayuca, Hidalgo: (a). plantation, (b). tree, (c). flower, (d). selected tree, (e). felling the tree, (f). log section showing the cross-section. 


\section{Laboratory procedure}

Two 5-cm slices were obtained from the first log section of each tree to determine the microscopic anatomical characteristics and the basic density; also, three $10-\mathrm{cm}$ slices were obtained to determine the radial, tangential and axial shrinkages, and two $20-\mathrm{cm}$ ones were obtained to evaluate the macroscopic characteristics.

\section{Macroscopic anatomical study}

Small boards measuring $1 \times 7 \times 15 \mathrm{~cm}$ of the three typical sections (longitudinal-radial, longitudinal-tangential and crosswise) were used to describe the color, smell, taste, luster, grain, texture, figure, and porosity. The color of the wood was classified according to the Munsell (1975) table, the smell and taste using the senses of smell and taste, the luster according to Ortega et al. (1992), and the texture and grain according to Tortorelli (1956).

\section{Microscopic anatomical study}

Specimens of $2 \times 2 \times 2 \mathrm{~cm}^{3}$ were obtained from the first slice to make typical sections. They were placed in a digester at a pressure of $1 \frac{1}{2} \mathrm{~kg} / \mathrm{cm}^{2}$ for 30 minutes to be softened. Subsequently, the typical sections were made with a Leica microtome at a thickness of $15 \mu$; chips were cut from the same specimens to make the dissociated material, according to Navarro et al. (2005).

With the length, lumen diameter, total diameter of the fibers and wall thickness data, the rigidity coefficient (RC), flexibility coefficient (FC), Peteri coefficient or slenderness index (SI) and Runkel's ratio (RR) were calculated (Tamarit 1996). The proportion of fibers, vessel elements, medullary rays and axial parenchyma were determined according to Machuca (1999), and the classification was based on Kollmann (1959). All measurements were performed with an image analyzer using LAS 3.1 software.

\section{Physical properties}

Saturated moisture content (SMC) and equilibrium moisture content (EMC) were determined according to Navarro et al. (2005). Fiber saturation point (FSP) denotes the moisture state of wood when it no longer contains free water, but its cell walls are saturated with hygroscopic water; to determine this property, the formula reported by Fuentes (2000) was used.

Wood density is influenced by its moisture content (MC); for this reason the following densities were determined: basic density, anhydrous density, equilibrium density, normal density and saturated density. These were evaluated according to standard NOM EE-117-1981 (Dirección General de Normas 1981) and were classified according to Vignote and Jiménez (1996).

Wood shrinkage refers to changes in its dimensions and volume, as a result of changes in moisture content below FSP, i.e. within the hygroscopic water. To determine partial and total volumetric shrinkage, and total radial, tangential and axial shrinkages, Mexican standard NMX-EE-167-1983 was used.

The volumetric shrinkage coefficient $(\mathrm{V} \beta \mathrm{v})$ is the shrinkage experienced by the wood for every $1 \%$ moisture decrease within the hygroscopic water range from the FSP, and reflects part of the degree of dimensional stability that characterizes the wood, calculated according to Fuentes (1998).

The anisotropy ratio (A) is a value that allows inferring the degree of dimensional stability of wood, showing the ratio between the magnitudes of total tangential shrinkage $(\% \beta R t)$ and total radial shrinkage (\%ßRt); it was calculated according to Fuentes (1998). 


\section{Mechanical properties}

Mechanical properties refer to the ability of wood to withstand external forces, such as tensile strength, elasticity and/or rigidity and hardness. These were estimated with mathematical formulas for broadleaf trees described by Brown and Panshin (1980).

\section{RESULTS}

\section{Anatomical characteristics}

\section{Macroscopic characteristics}

Table 2 and Figure 3 show the macroscopic characteristics of Acacia schaffneri wood.

Table 2. Macroscopic characteristics of wood of Acacia schaffneri.

\begin{tabular}{|l|l|l|}
\hline \multicolumn{2}{|c|}{ Characteristic } & \multicolumn{2}{c|}{ Description } \\
\hline \multirow{2}{*}{ Color } & Sapwood & HUE 2.5Y(8/4) Very pale yellow \\
\cline { 2 - 3 } & Heartwood & HUE 2.5YR(3/4) dark reddish brown \\
\hline Smell & Presents \\
\hline Taste & Presents \\
\hline Grain & Interlocked \\
\hline Texture & Fine to medium \\
\hline Figure & Pronounced (presents dark lines) \\
\hline Luster & High \\
\hline Ray visibility & Rays visible with a magnifying glass \\
\hline
\end{tabular}



Figure 3. Typical macroscopic sections of the wood of Acacia schaffneri. (a): cross-section, (b): radial section, (c): tangential section 
The wood of Acacia schaffneri is similar in color, grain and texture to A. melanoxylum, A. acuminata, A. arabica, A. koa, A. cambagei, A. catechu, A. aneura (Kribs 1968, Monteoliva and Igartúa 2010), A. articulata, A. macracantha, A. polyphylla (Williams 2008) and Acacia gaumeri (Rebollar and Quintanar 1998). The wood of Acacia schaffneri, by having a pronounced figure, can be used for fine cutlery, flooring, and sliced panels for later veneering boards, which coincides with the findings reported by Huicochea-Santana and Barajas-Morales in 2002 for the species Acacia farnesiana; in Portugal the wood of genus Acacia was used in ecclesiastical furniture because of its durability (Bernal et al. 2011).

\section{Microscopic characteristics}

In Table 3 and Figures 4 and 5 it can be seen that the microscopic characteristics of Acacia schaffneri, in terms of porosity, fibers, vessel element pits, parenchyma and rays, are similar to those of Acacia acuminata, A. arabica, A. koa, A. melanoxylum, A. cambagie, and A. catechur (Kribs 1968). The number of vessels per $\mathrm{mm}^{2}$, tangential diameter, fiber diameter and ray height are similar to $A$. cynophylla but differ numerically from A. mangium (Van der Graaff and Baas 1974) and A. macracantha (Silva et al. 1989). The concentric parenchyma can be considered as denoting growth rings, as in other African Acacias (Gourlay 1995 a,b). Compared with other Acacia species that grow in Mexico, such as Acacia cochliacantha, which is distributed on the Pacific slope, Acacia bilimecki in Guerrero, Morelos, Oaxaca and Puebla and Acacia gaumeri in Quintana Roo, Acacia schaffneri is similar to all of them in type of porosity, tangential diameter, simple plate, alternate pits, type of parenchyma, rays, fiber, and cell contents, (Rebollar and Quintanar 1998, Huicochea-Santana and Barajas-Morales 2002), such as the crystals that in developed species in very arid areas may have a reserve of calcium (Gourlay and Grime 1994).

However, it is different in relation to the type of porosity, which is semicircular in Acacia angustissima (Aguilar-Alcantara et al. 2014).

Table 3. Microscopic characteristics of the wood of Acacia schaffneri.

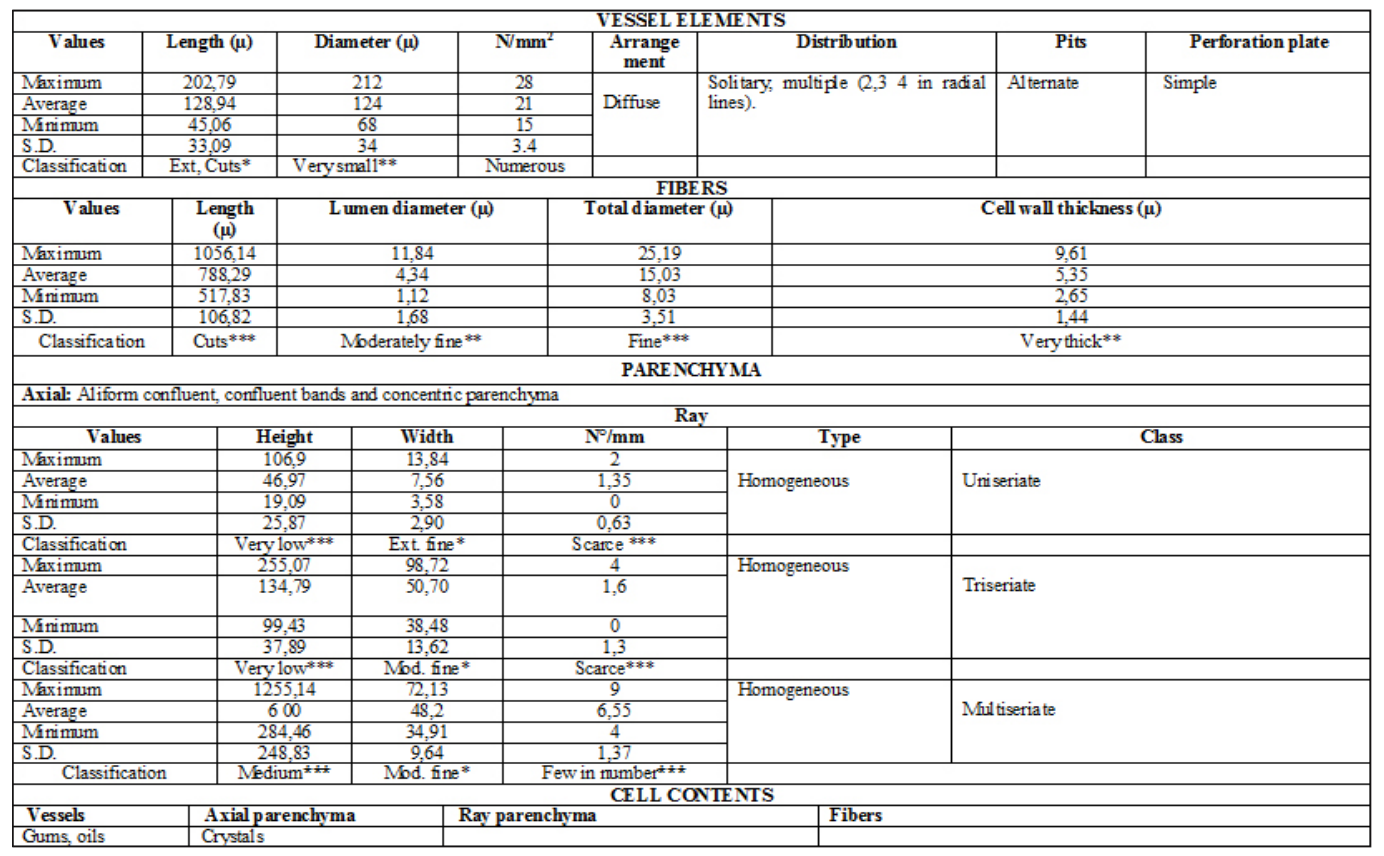

S.D: Standard deviation Jane (1970)*, Terrazas (1984)**, Tortorelli (1956)***. Ext. Extremely, Mod. Moderately. 

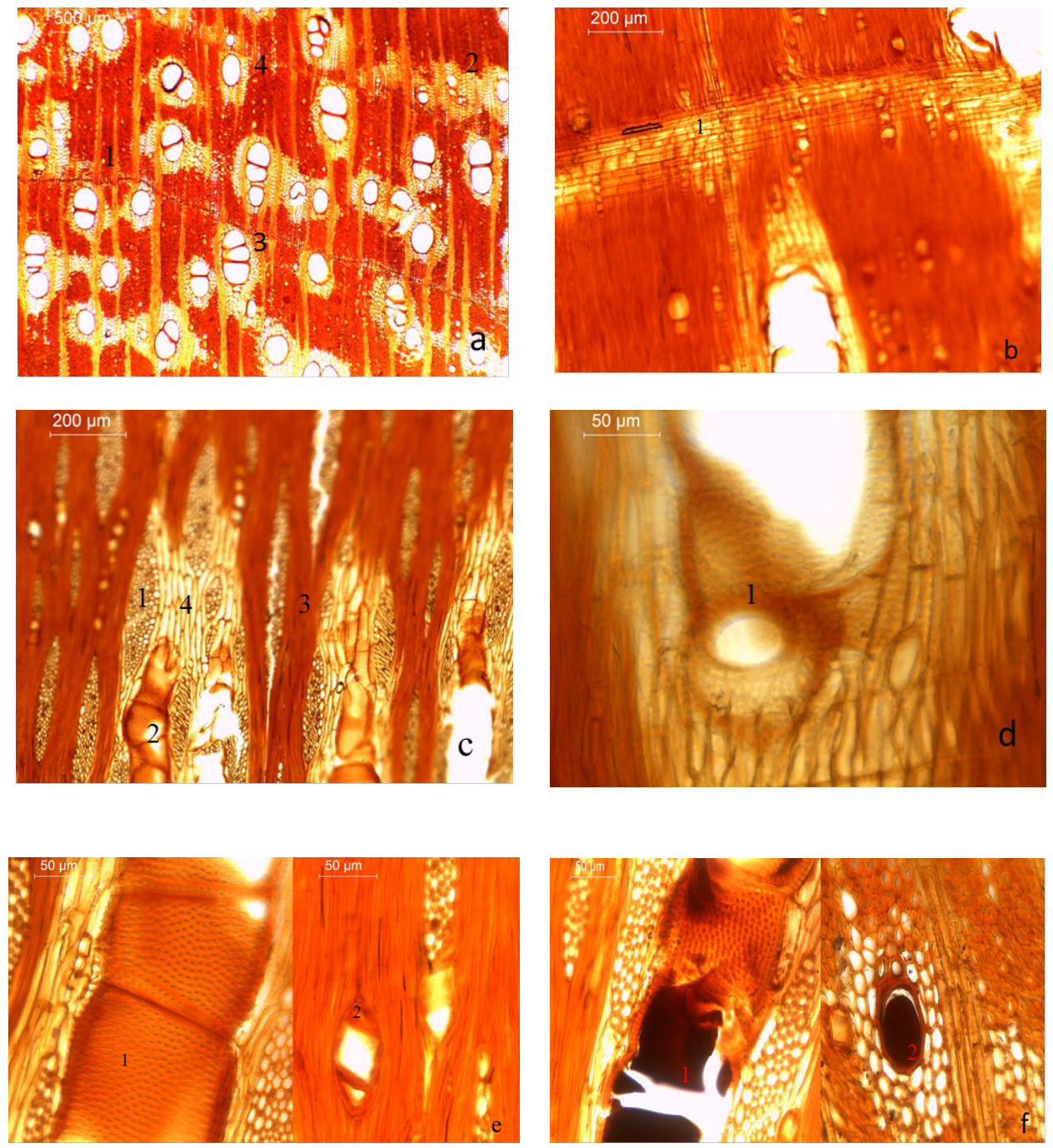

Figure 4. Anatomical characteristics of the wood of Acacia schaffneri.

(a): cross section (1. concentric parenchyma, 2. parenchyma in confluent bands, 3. multiple vessels, 4 . solitary vessel),

(b): radial section (1. ray),

(c): tangential section (1. multiseriate ray, 2. vessel element,

3. fibers, 4. axial parenchyma),

(d): radial section (1. simple plate),

(e): tangential section (1. alternate pits,

2. rhomboid crystal),

(f): tangential section (1 gum in vessel element);. cross section (2 gums in vessel) 

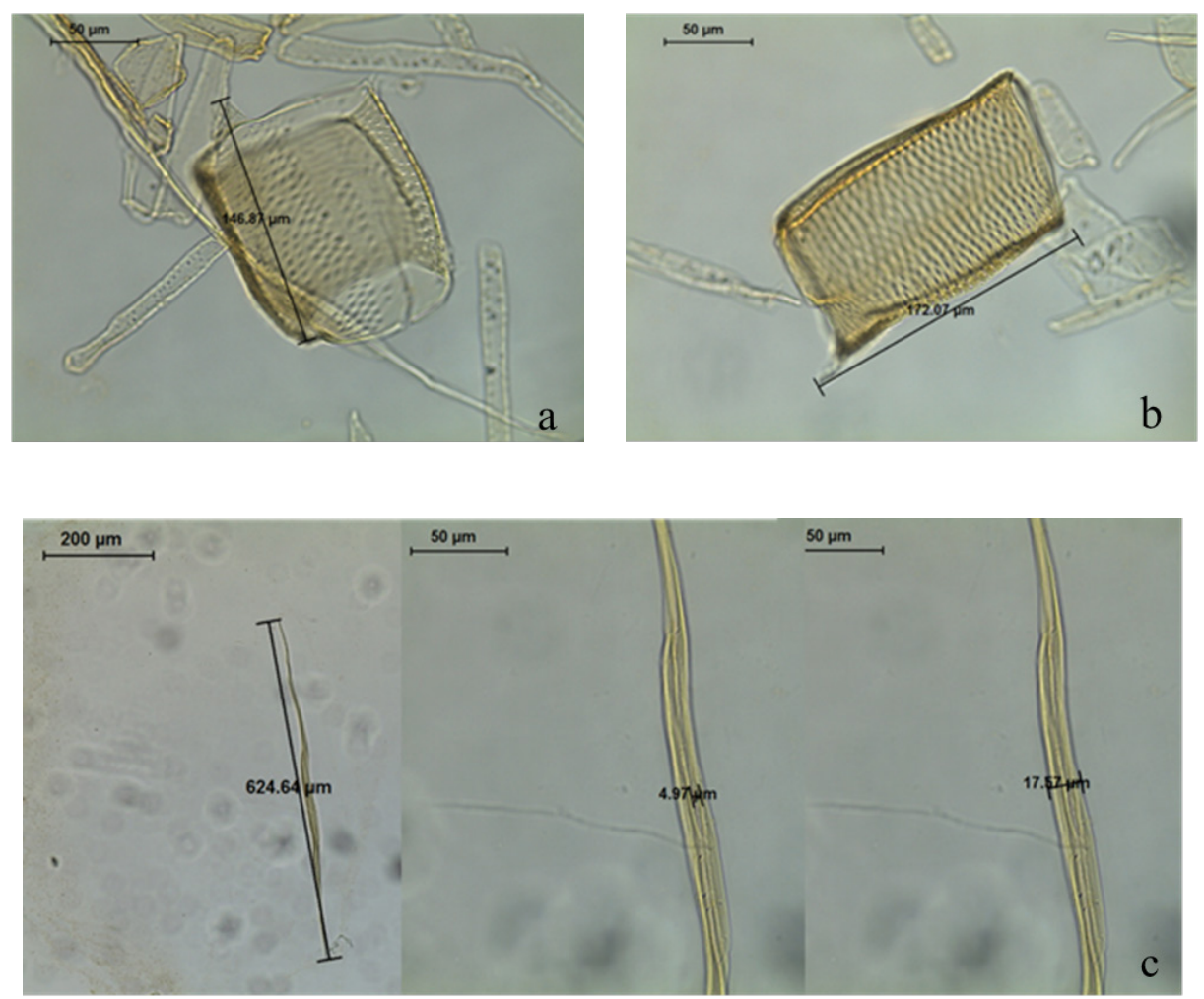

Figure 5. Individualized cells of the wood of Acacia schaffneri.

(a): vessel element, parenchymal cell and fiber. (b): vessel element. (c): fiber

\section{Proportion of constituent elements}

Table 4 shows the results of the proportion of constituent elements in the wood.

By comparing the proportion of constituent elements reported by Bravo et al. 2006, in Acacia aroma, which has $10,4 \%$ vessels $36,2 \%$ fibers $32,2 \%$ axial parenchyma and $21,2 \%$ ray parenchyma, and in Acacia furcatispina, which has $21,8 \%$ vessels $42,0 \%$ fibers $28,4 \%$ axial parenchyma and 7,8\% ray parenchyma, it can be seen that the values obtained in this study are between those of the two species.

Table 4. Proportion of constituent elements in the wood of Acacia schaffneri.

\begin{tabular}{|l|c|c|c|c|}
\hline \multirow{2}{*}{ Value } & \multicolumn{4}{|c|}{ Cell percentage } \\
\cline { 2 - 5 } & Vessel element & Fibers & Axial parenchyma & Ray parenchyma \\
\hline Maximum & 20,4 & 55,2 & 32,2 & 14,2 \\
\hline Average & 11,78 & 50,65 & 27,76 & 9,81 \\
\hline Minimum & 6,7 & 43,2 & 21 & 7 \\
\hline S.D. & 5,47 & 4,93 & 4,59 & 2,93 \\
\hline $\begin{array}{l}\text { Classification } \\
\text { Kollmann (1959) }\end{array}$ & Average & Average & Average & Lower \\
\hline
\end{tabular}




\section{Pulp quality indices}

The wood fibers of Acacia schaffneri have a very thick wall so that they do not collapse and the contact surface is small, so the fiber-to-fiber bonding is poor; consequently, paper made from this type of fiber has low tensile strength. Moreover, Runkel's ratio of Acacia schaffneri was classified as bad for paper (Table 5), which is very different from that of Acacia melanoxylum, which is classified as good, despite both being of the same family (Tamarit 1996). Other species such as Acacia mearnsii and $A$. dealbata planted in Chile provide high-performance wood pulps (Pinilla et al. 2006).

Table 5. Pulp quality indices of the wood of Acacia schaffneri.

\begin{tabular}{|c|c|c|c|c|}
\hline \multirow{2}{*}{ Values } & \multicolumn{4}{|c|}{ Pulp quality indices } \\
\cline { 2 - 5 } & R.C.: 2W/D & F.C.: I/D & S.I.: L/D & R.R: 2W/I \\
\hline Maximum & 0,90 & 0,59 & 91,05 & 8,68 \\
\hline Average & 0,71 & 0,29 & 54,92 & 2,73 \\
\hline Minimum & 0,41 & 0,10 & 28,39 & 0,69 \\
\hline S.D. & 0,09 & 0,09 & 13,77 & 1,25 \\
\hline Classification & Thick & Very thick & Not found & Bad for paper \\
\hline
\end{tabular}

R.C. Rigidity coefficient. 2WD Fiber wall thickness/Fiber diameter. F.C. Flexibility coefficient. I/D Lumen diameter/Fiber diameter.

S.I. Slenderness index. L/D Fiber length/Fiber diameter. R.R. Runkel's ratio. 2W/I Fiber wall thickness/lumen diameter.

\section{Physical properties}

\section{Wood density}

Density is one of the most important technological properties of wood and constitutes an excellent evaluation criterion, given its close relationship with other characteristics of this material (Díazvaz and Ojeda 1980). Table 6 shows that the wood, based on its basic and normal density, is classified as very heavy (Vignote and Jiménez 1996).

Basic density was $880 \mathrm{~kg} / \mathrm{m}^{3}$, which is different from the value reported by Carrillo et al. (2011) and Foroughbakhch et al. (2012), which was $790 \mathrm{~kg} / \mathrm{m}^{3}$. However, Morales (2002) reported for Acacia bilimecki a range of 880 to $970 \mathrm{~kg} / \mathrm{m}^{3}$; this density is similar to that of $A$. schaffneri, but different than that of Acacia cochliacantha, $940 \mathrm{~kg} / \mathrm{m}^{3}$, reported by the same author. Similar data were reported by Bravo et al. (2006): $890 \mathrm{~kg} / \mathrm{m}^{3}$ for A. aroma and $990 \mathrm{~kg} / \mathrm{m}^{3}$ for $A$. furcatispina. It is also similar to Acacia acuminata $\left(960 \mathrm{~kg} / \mathrm{m}^{3}\right)$, A. arabica $\left(800 \mathrm{~kg} / \mathrm{m}^{3}\right)$, A. koa $\left(830 \mathrm{~kg} / \mathrm{m}^{3}\right)$, A. melanoxylum $(720 \mathrm{~kg} /$ $\left.\mathrm{m}^{3}\right)$, A. cambagie $\left(750 \mathrm{~kg} / \mathrm{m}^{3}\right)$, but different than A. catechu $\left(980 \mathrm{~kg} / \mathrm{m}^{3}\right)$, A. aneura $\left(1200 \mathrm{~kg} / \mathrm{m}^{3}\right)(\mathrm{Kribs}$ 1968 ) and Acacia mangium (450 kg/m $\mathrm{m}^{3}$ ) (Muñoz and Moreno 2013).

Table 6. Wood density of Acacia schaffneri.

\begin{tabular}{|l|c|c|c|c|c|}
\hline & \multicolumn{5}{|c|}{ Types of density kg/m } \\
\hline \multicolumn{1}{|c|}{ Values } & $\begin{array}{c}\text { Green } \\
\text { density }\end{array}$ & $\begin{array}{c}\text { Moisture content } \\
\text { density h }\end{array}$ & Normal density & Basic density & $\begin{array}{c}\text { Anhydrous } \\
\text { density }\end{array}$ \\
\hline Maximum & 1290 & 1150 & 1180 & 1000 & 1120 \\
\hline Average & 1180 & 1010 & 1002 & 880 & 980 \\
\hline Minimum & 1110 & 740 & 720 & 590 & 670 \\
\hline S.D. & 50 & 140 & 140 & 130 & 140 \\
\hline Classification & & & Very heavy, (Díaz 1960) & $\begin{array}{l}\text { Very heavy, (Vignote } \\
\text { and Jiménez 1996) }\end{array}$ \\
\hline
\end{tabular}




\section{Shrinkage}

Shrinkage refers to changes in dimensions that wood experiences as a result of water loss (moisture content) below the FSP. Changes in dimensions due to shrinkage are related to the cell structure, and are manifested according to the structural axis of the wood where the measurement of the wood samples is performed. Table 7 shows the values of the different types of shrinkages found in this study.

Acacia schaffneri presented tangential and radial shrinkage values lower than those of Acacia melanoxylon and Acacia dealbata, although the shrinkages of these species are at 12\% MC (Ananías et al. 2008, Igartúa et al. 2009).

Table 7. Total shrinkages of the wood of Acacia schaffneri.

\begin{tabular}{|l|c|c|c|c|}
\hline & \multicolumn{4}{|c|}{ Types of shrinkage (\%) } \\
\hline \multicolumn{1}{|c|}{ Values } & Tangential & Radial & Axial & Volumetric \\
\hline Maximum & 13,14 & 7,39 & 0,010 & 18,59 \\
\hline Average & 10,17 & 4,97 & 0,010 & 15,82 \\
\hline Minimum & 7,51 & 3,07 & 0,010 & 14,16 \\
\hline S.D. & 1,37 & 1,06 & 0,005 & 1,32 \\
\hline Classification & $\begin{array}{c}\text { Very high (Fuentes } \text { et } \\
\text { al. 2002) }\end{array}$ & High (Fuentes et al. 2002) & & $\begin{array}{c}\text { High (Vignote and } \\
\text { Jiménez 1996) }\end{array}$ \\
\hline
\end{tabular}

S.D. Standard deviation

\section{Other physical properties}

Table 8 shows the fiber saturation point, volumetric shrinkage coefficient and anisotropy ratio results.

Table 8. Fiber saturation point, volumetric shrinkage coefficient and anisotropy ratio of the wood of Acacia schaffneri.

\begin{tabular}{|l|c|c|c|}
\hline \multicolumn{1}{|c|}{ Values } & FSP & VSC & A.R. \\
\hline Maximum & 23,48 & 0,79 & 3,66 \\
\hline Average & 19,97 & 0,79 & 2,12 \\
\hline Minimum & 17,88 & 0,79 & 1,36 \\
\hline S.D. & 1,67 & $1,33432 \mathrm{E}-16$ & 0,54 \\
\hline \multirow{2}{*}{ Classification } & $\begin{array}{c}\text { Lower (Kollmann; } \\
1959)\end{array}$ & $\begin{array}{c}\text { High, (Vignote and } \\
\text { Jiménez; 1996) }\end{array}$ & High (Fuentes; 1998). \\
\hline
\end{tabular}

FSP: Fiber saturation point, VSC: Volumetric shrinkage coefficient, A.R. Anisotropy ratio

The fiber saturation point of the fibers was lower than that of Acacia melanoxylon at $24.7 \%$ moisture content (Igartúa et al. 2009).

Considering the results shown in Tables 8 and 9, Acacia schaffneri wood has high shrinkage values, both linear and volumetric, as well as for the volumetric shrinkage coefficient, indicating that the drying process for this wood should be initiated with a soft schedule, but it showed higher values compared to Acacia mangium (Muñoz and Moreno 2013), which may be due to this species having a low density. 


\section{Mechanical properties}

Table 9 shows that all the mechanical properties are classified as very high. The data reported by Carrillo et al. (2011) and Foroughbakhch et al. (2012) are similar to those reported in this study, so this species can be used in structural applications in construction. The mechanical properties can be compared with those of Acacia polyphylla. D.C., which has a basic density of $520 \mathrm{~kg} / \mathrm{m}^{3}$; this is less than that of Acacia schaffneri and, therefore, its mechanical properties are lower. For example, $A$. polyphylla has $38,5 \mathrm{MPa}$ in stress at proportional limit, modulus of rupture of $71,1 \mathrm{MPa}$ and modulus of elasticity of 1,2 GPa in the bending test, along with transversal and side hardness values of $596,3 \mathrm{~kg}$ and 426,9 $\mathrm{kg}$ respectively (Aróstegui and Sato 1970); it is the same situation for A. melanoxylon, which has the following values: basic density of $560 \mathrm{~kg} / \mathrm{m}^{3}$; in the bending test, stress at proportional limit of 37,7 MPa, modulus of rupture of $89,9 \mathrm{MPa}$ and modulus of elasticity of $10,9 \mathrm{GPa}$; transversal and side hardness of $546,72 \mathrm{~kg}$ and $416 \mathrm{~kg}$, respectively (Igartúa et al. 2015). The results in this research are compared to studies of the genus Acacia, because there is little information available on the wood of Acacia schaffneri.

Table 9. Mechanical properties calculated from mathematical formulas of the wood of Acacia schaffneri.

\begin{tabular}{|c|c|c|c|c|}
\hline Test & Green condition & Classification & $12 \%$ Condition & Classification \\
\hline \multicolumn{5}{|c|}{ Static bending } \\
\hline Stress at proportional limit (MPa) & 59,1 & Average & 118,0 & Very high* \\
\hline Modulus of rupture $(\mathrm{MPa})$ & 103,4 & Average & 181,6 & Very high* \\
\hline Modulus of elasticity (GPa) & 14,3 & Average & 19,7 & Very high* \\
\hline \multicolumn{5}{|c|}{ Impact } \\
\hline Impact $(\mathrm{cm})$ & 231,52 & Very high & 248,76 & Very high* \\
\hline \multicolumn{5}{|c|}{ Compression parallel to fiber } \\
\hline Stress at proportional limit (MPa) & 31,9 & Low & 61,6 & Very high** \\
\hline Maximum stress (MPa) & 40,8 & & 85,8 & Very high*** \\
\hline Modulus of elasticity (GPa) & 180,0 & Average & 23,8 & Very high \\
\hline \multicolumn{5}{|c|}{ Compression perpendicular to fiber } \\
\hline Stress at proportional limit (MPa) & 15,5 & Average & 33,4 & Very high* \\
\hline \multicolumn{5}{|c|}{ Hardness } \\
\hline Side $(\mathrm{kg})$ & 1272,40 & High & 2276,44 & Very high*** \\
\hline Extreme $(\mathrm{kg})$ & 1163,53 & Very high & 1787,96 & Very high*** \\
\hline
\end{tabular}




\section{CONCLUSIONS}

The wood of Acacia schaffneri can be used for making fine pieces for various items such as furniture and flooring, among others, but it is not good for making pulp for paper.

Due to the wood density of Acacia schaffneri, it is defined as a heavy wood that can be used for the manufacture of heavily-trafficked floors.

The wood of Acacia schaffneri is classified as high strength, so it can be used in constructing buildings, heavy platforms, marine structures and posts.

\section{REFERENCES}

Aguilar-Alcántara, M.; Aguilar-Rodríguez, S.; Terrazas, T. 2014. Anatomía de la madera de doce especies de un bosque mesófilo de montaña de Tamaulipas, México. Madera y Bosques 20(3): 69-86.

Ananías, R.A.; Salvo, L.; Estrada, R.; Briones, R. 2008. Estudio experimental del secado a temperaturas convencionales de acacias. Maderas. Ciencia y tecnología 10(2):151-162.

Arostegui, A.; Sato, A. 1970. Estudio de las Propiedades Físico-Mecánicas de la madera de 16 especies Forestales del Perú. Revista Forestal del Perú 4(1-2):1-13

Barros, S. 2007. El género Acacia, especies multipropósito. Ciencia e Investigación Forestal (Número Extraordinario):5-30.

Bernal, R.A.; Valente, A.; Pissarra, J. 2011. Eighteenth Century Technological Efficiency: The Reuse of Brazilian Sugar Chest Wood in Portuguese Cabinet Manufacture. International Journal of Conservation Science (2)4: 217-228

Bravo, S.; Giménez, A.; Moglia, J. 2006. Caracterización anatómica del leño y evolución del crecimiento en ejemplares de Acacia aroma y Acacia furcatispina en la Región Chaqueña, Argentina. Bosque 27(2): 146-154.

Brown, H.P.; Panshin, A. J. 1980. Textbook of wood technology: The physical, mechanical and chemical properties of the commercial woods of the United States. Vol. II (3a. Ed). New York, Toronto, London: McGraw-Hill Book Company

Carrillo, A.; Garza, M.; Nañez, M. de J.; Garza, F.; Foroughbakhch, R.; Sandoval, S. 2011 Physical and mechanical wood properties of 14 timber species from Northeast Mexico. Annals of Forest Science. 68:675-679 DOI.10.1007/s13595-011-0083-1.

CONAFOR. 2008. Comisión Nacional Forestal Coordinación General de Educación y Desarrollo Tecnológico Gerencia de Desarrollo y Transferencia de Tecnología Catálogo de contenido de carbono en especies forestales de tipo arbóreo del noreste de México. www.conafor.gob.mx/conacyt-conafor

Correa, J.R.A. 2011. Clasificación y evaluación del mercado de madera aserrada de Aromo australiano (Acacia melanoxylon R.Br.) Universidad Austral de Chile Valdivia 57p. 
Dávalos, S.R.; Bárcenas, P.G. 1999. Clasificación de las Propiedades Mecánicas de las Maderas Mexicanas. Madera y Bosques 5(1):61-69.

Díaz, G., V.1960.Métodos de ensayo para determinar las propiedades físicas y mecánicas de la madera .Unidad y Enseñanza e Investigación en Bosques. Escuela nacional de Agricultura. Chapingo, Texcoco, México

Dirección General de Normas. D.G.N. 1981. Envase y embalaje. Determinación de peso específico aparente en maderas. Secretaría de patrimonio y fomento industrial. NOM-EE-117-1981. México, D.F. 6 p.

Dirección General de Normas. D.G.N. 1983. Envase y embalaje Madera Contracción líneal. Método de prueba. Secretaría de patrimonio y fomento industrial. NOM-EE-167-1983. México, D.F. $7 \mathrm{p}$.

Díaz vaz, J.E.; Ojeda, F. 1980. Densidad Intraincremental de Pseudotsuga menziesii 1: variaciones en un análisis fustal. Bosque 3(2): 86-95.

Echenique, M.R. ; Plumptre, R.A. 1994. Guía para el uso de maderas de México y Belice. Universidad de Guadalajara, Consejo Británico, Universidad de Oxford. México.196p.

Fuentes, S.M. 1998. Propiedades Tecnológicas de las maderas mexicanas de importancia en la construcción. Revista Chapingo Serie Ciencias Forestales y del Ambiente 4(1): 221-229.

Fuentes, S.M. 2000. Estimación del punto de saturación de la fibra (PSF) de las maderas. Revista Chapingo, Serie Ciencias Forestales y del Ambiente 6 (1): 79-81.

Fuentes, T. F.J.; Silva, G. J.A.; Lomelí, R. M.G.; Richter, H.G.; Sanjuan, D.R. 2002 Comportamiento higroscópico de la madera de Persea americana var. Guatemalensis Mill (Hass). Revista Chapingo Serie Ciencias Forestales y del Ambiente 8(1): 49-56.

Foroughbakhch, R.; Carrillo, A.P.; Hernández, J.L.; Alvarado, M.A.; Rocha, A.E.; Cardenas, M. L. 2012. Wood Volume Production and Use of 10 Woody Species in Semiarid Zones of Northeastern Mexico. International Journal of Forestry Research 7p. doi:10.1155/2012/529829.

Gómez, A.S.L.; Tapia, F.P. 2003. Estudio genecológico en Prosopis laevigata, Acacia farnesiana y Acacia schaffneri (leguminosae). Darwiniana 41(1-4): 47-54.

González, H.M.E. 2007. Establecimiento y crecimiento en sus primeras etapas de diez especies arbustivas nativas, en la microcuenca de Santa Rosa Jáuregui, Querétaro. Universidad Autónoma de Querétaro, tesis de Maestro en gestión de Cuencas. México.108p.

Gourlay, I.D.; Grime, G.W. 1994. Calcium oxalate crystals in African Acacia species and their analysis by scanning proton microprobe (SPM). lAWA Journal 15 (2): 137-148.

Gourlay, I.D. 1995a. Growth ring characteristics of some African Acacia species. Journal of Tropical Ecology 11:121-140.

Gourlay, I.D. 1995b. The Definition of Seasonal Growth Zones in Some African Acacia species A Review. IAWA journal 16 (4): 353-359.

Huicochea-Santana, G.; Barajas-Morales, J. 2002. Manual de Manejo Forestal de Especies Espinosas. Serie Forestal 1.Fundación Produce de Guerrero A.C., Chilpancingo, Gro. 17p. [Disponible en: $]<$ http://www.significado-s.com/e/acacia/ $>[28$ de diciembre de 2016]

Igartúa, D.V.; Monteoliva, S.; Piter, J.C. 2009. Estudio de algunas propiedades físicas de la madera de Acacia melanoxylon R. Br. En Argentina. Maderas. Ciencia y Tecnología 11(1):3-18. 
Igartúa, D.V.; Moreno, K.; Piter, J.C.; Monteoliva, S. 2015. Densidad y Propiedades Mecánicas de la Madera de Acacia melanoxylon implantada en Argentina. Maderas: Ciencia y Tecnología 17(4): 809-820.

Jane, F.W. 1970. The structure of wood. New York : Mc. Millan.

Kollmann, F. 1959. Tecnología de la Madera y sus aplicaciones. Ministerio de Agricultura. Instituto Forestal de Investigaciones, Experiencias y Servicio de la Madera. Madrid, España. 675 p.

Kribs, D.A. 1968. Commercial foreign Woods on the American Market. Dover publications, Inc. New York. 241p.

Machuca, V.R.; Borja, A.; Bárcenas, G.P. 1999. Propiedades Tecnológicas de la madera de Quercus insignis de Huatusco estado de Veracruz, México. Revista Chapingo Serie Ciencias Forestales 5(2): 113-123.

Manríquez, T. J. 2013. Principios activos anticancerígenos y antiinflamatorios de Acacia schaffneri. Tesis de Doctorado en Química, Universidad Autónoma del estado de Hidalgo .147.

Monteoliva, S.; Igartúa, D.V. 2010. Variación anatómica de la madera de Acacia melanoxylon implantada en el sudeste de la provincia de Buenos Aires Revista de la Facultad de Agronomía, La Plata. 109 (1): 1-7

Munsell Color. 1975. Munsell soil color charts. Baltimore, Maryland.

Muñoz-Acosta, F.; Moreno-Perez , P. A. 2013. Contracciones y Propiedades Físicas de Acacia mangium Willd., Tectona grandis L. F. y Terminalia amazonia A. Chev, Maderas de Plantación en Costa Rica. Revista Chapingo Serie Ciencias Forestales y del Ambiente 19(2):287-303.

Navarro, M.J; Borja, A.; Machuca, R. 2005. Características Tecnológicas de la Madera de Palo Morado (Peltogyne mexicana Martínez) de Tierra Colorada, Guerrero. Revista Chapingo Serie Ciencias Forestales y del Ambiente 11(1): 73-82.

Ortega, G.L.; Carmona, F.; Cordoba, C. 1992. Anatomía de la madera de 28 especies de Cosautlán de Carvajal, Veracruz. Angiospermas arbóreas de México Núm. 1. La madera y su uso. Bol. Tec. Núm. 19. LICITEMA. Instituto de Ecología A. C. Xalapa, Ver. 605p.

Pinilla, J.C.; Molina, M.P.; Briones, R.; Hernández, G. 2006. Opciones de productos a partir de la madera de Acacia y su producción. Antecedentes de una experiencia con Acacia en Chile. Boletín del CIDEU 2: 73-92.

Rebollar, S.; Quintanar, A. 1998. Anatomía y usos de la madera de ocho especies tropicales de Quintana Roo, México. Rev Biol Trop 46(4): 1047-1057.

Rico-Arce, M.L. 2001. El género Acacia (Leguminosae,Mimosoideae) en el estado de Oaxaca, México. Anales Jard Bot 58(2):251-302.

Silva, A.; Blanco, C.; Lindorf, H. 1989. Anatomia de la Madera de Nueve Leguminosas de Venezuela. Acta Bot Bras 2(1): 115-134.

Tamarit, U.J.C. 1996. Determinación de los índices de calidad de pulpa para papel de 132 maderas latifoliadas. Madera y Bosques 282:29-41.

Tortorelli, A. 1956. Maderas y Bosques de Argentina. Buenos Aires, Argentina: ACME. S.A.

Van der Graaff, N.A.; Baas, P. 1974. Wood anatomical variation in relation to latitude and altitude. BLUMEA 22:101-121.

Vignote, S.; Jimenez, F. 1996.Tecnología de la madera. Ministerio de Agricultura, Pesca y 
Alimentación. Madrid, España. 606p.

Williams, J.L.H. 2008. Anatomía de Madera en 31 Especies de la Subfamilia Mimosoideae (leguminosae) en Venezuela. Revista Colombia Forestal 11: 113-135. 